\title{
Impressed current cathodic protection with embedded anodes - field trial on the Viaduc de Saint-Cloud in France
}

\author{
Véronique Bouteiller ${ }^{1, *}$, Guillaume Damien ${ }^{2}$, Frédéric Boinski ${ }^{3}$, Julien Schneider ${ }^{3}$, and Christophe Michaux ${ }^{4}$ \\ ${ }^{1}$ Université Paris-Est, EMGCU - MAST - IFSTTAR, 77447 Marne-la-Vallée, France \\ ${ }^{2}$ DRIEA, IF/DiRIF/SIMEER/DIOA, France \\ ${ }^{3}$ Cerema, Direction territoriale Ile-de-France, LEM, France \\ ${ }^{4}$ In-Situ SA, Luxembourg
}

\begin{abstract}
This paper deals with the electrochemical repair of a road bridge, Viaduc de Saint-Cloud which was constructed in the 1970's in France. In 2011, a corrosion analysis was performed together with a durability study. It was demonstrated that the corrosion was induced by chloride ions coming from de-icing salts leaking from the deck. The induced corrosion was increased by the low cover depths resulting in a chloride penetration beyond the reinforcement depth. In order to evaluate the effectiveness and the reliability of Impressed Current Cathodic Protection (ICCP) with embedded anodes, a field trial was performed in 2012 on three span segments including one segment over pier (P2). The results of the ICCP design, the implementation and the monitoring are presented. It was found that two months were necessary before the cathodic protection would reach an equilibrium. Performance criteria as described in ISO 12696 dealing with cathodic protection passed on two segments but failed on the segment over pier. On the latter, where the congestion of reinforcement and prestressed tendons was higher, the anodic system needed some improvement. Finally, the results of the field trial allowed proposing a technical and an economic repair solution.
\end{abstract}

\section{PRESENTATION OF THE BRIDGE}

Viaduc de Saint-Cloud was constructed in the 1970s in France (Fig. 1) [1]. It belongs to the A13 highway just west from downtown Paris and allows more than 120000 vehicles per day to cross the River Seine between SaintCloud and Boulogne. The span length is 1100 meters. The viaduct is constituted by three-cell box girders (Fig. 2).

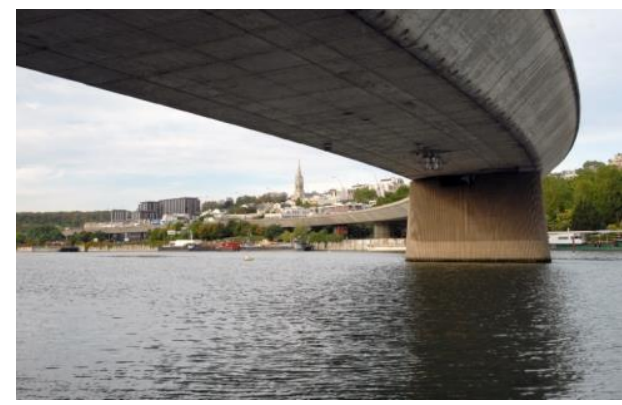

Fig. 1. Viaduc de Saint-Cloud (H. Delahousse, Ifsttar).

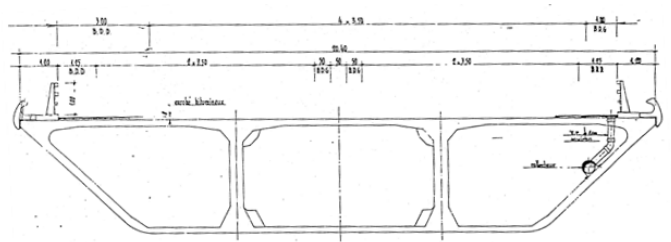

Fig. 2. Geometry of the segment: three-cell box girders.

\section{ASSESSMENT}

The bridge assessment was based on visual inspection, concrete durability and reinforcement corrosion investigations.

The results of a visual inspection and delamination survey (rust stains, concrete cracks or spalling damages) were helpful to define different areas from severe to negligible corroded zones. These results are gathered in Fig. 3. The field trial was done on pier P2 which was in a medium to severe state of corrosion and which has easier access (Fig. 4).

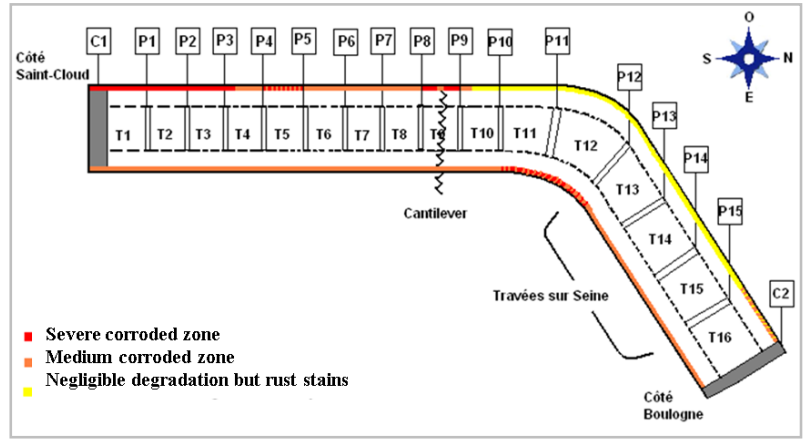

Fig. 3. Visual inspection results of the bridge. 


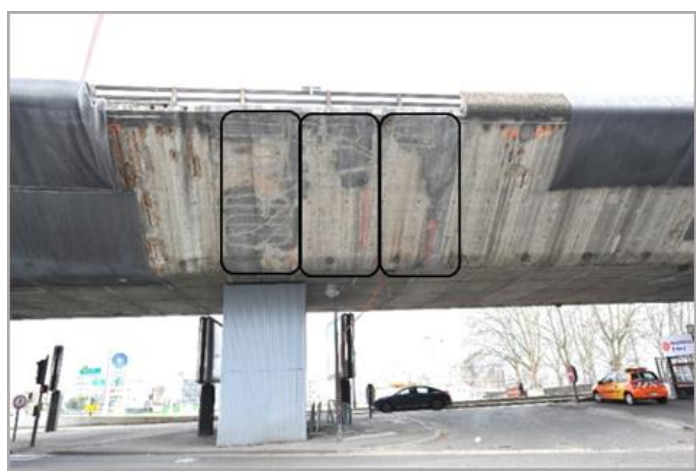

Fig. 4. Field trial on the three segments on pier P2 (from left to right: one segment over pier P2-0 and two span segments P2-1 and $\mathrm{P} 2-2$ ).

Fig. 5 presents the locations of the chloride cores in the segments and the chloride profiles versus concrete depth of the durability investigation [2]. Results show that chlorides have penetrated into the concrete deeper than the reinforcement which was at 10 to $20 \mathrm{~mm}$. Chlorides came from de-icing salts that were spread on the bridge in winter and that penetrated the concrete cover leaking through the waterproofing protection and flowing along the segments. It was concluded that the major cause of concrete deterioration was chloride induced corrosion of the steel. Concrete carbonation depth was less than $10 \mathrm{~mm}$.

Fig.6 represents the half-cell potential mappings for each segment [3]. From corrosion diagnosis, half-cell potential measurements were in the range 0 to $-500 \mathrm{mV}$. The results were consistent with a high probability of corrosion as demonstrated by the gradients in Fig. 6 .

\section{FIELD TRIAL}

\subsection{Rehabilitation technique}

Classical "patch repair" had failed in $50 \%$ of cases after 10 years according to the European ConRepNet Project [4]. The two main causes of failure are debonding between original concrete and new concrete and the incipient anode effect (mainly in the case of chloride contaminated structures) $[4,5]$. In the case of the Viaduc de Saint-Cloud this classical repair technique, including removal of contaminated concrete and application of new concrete, was not compatible with the heavy traffic and the structural load capacity of the bridge.

Cathodic protection is the only technology that can directly stop corrosion in reinforced concrete structures if designed, installed, and operated correctly [5-9]. Cathodic protection systems are capable of providing a significantly larger extension in service life depending on the service life of the anode material and the maintenance of the system. In order to address the corrosion problem of the Viaduc de Saint-Cloud, Cathodic Protection rehabilitation treatment was therefore proposed in accordance with NF EN ISO 12696 standard [10].
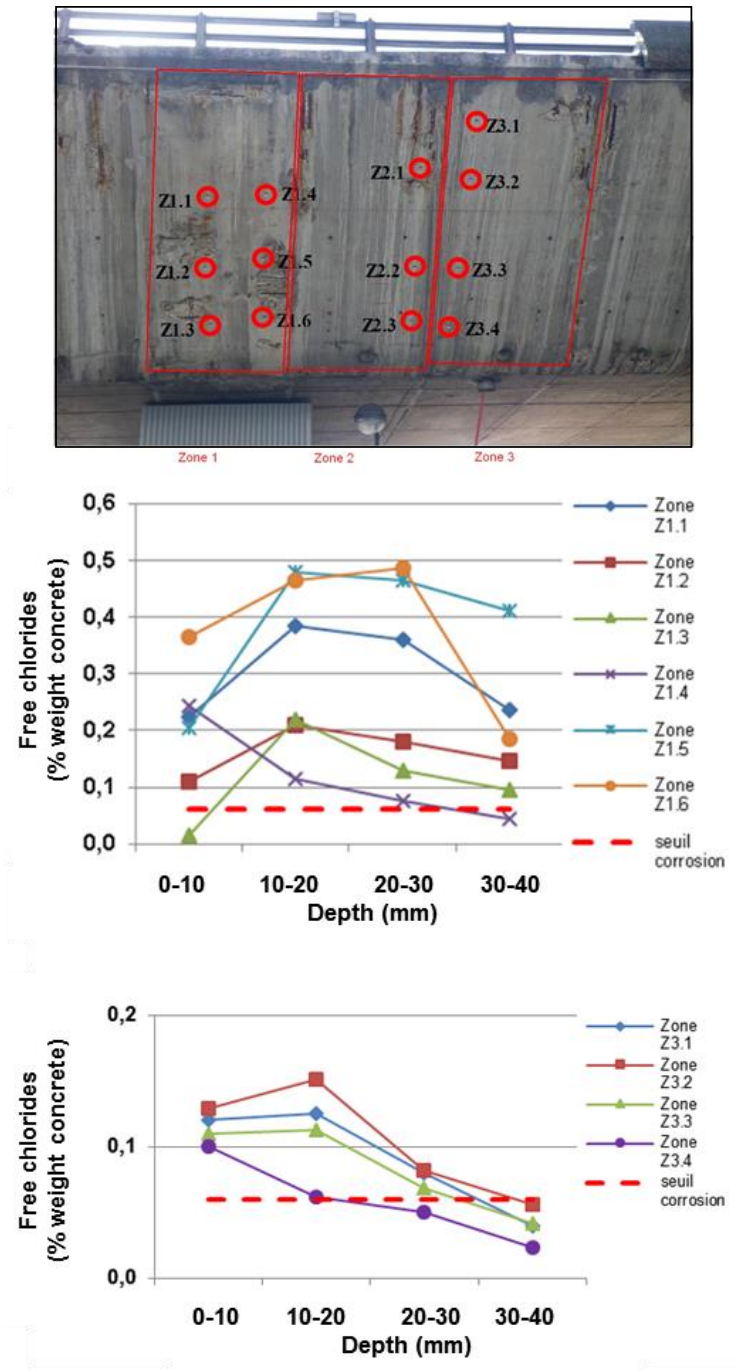

Fig. 5. Locations of concrete cores (top) and free chloride profiles versus depth on segment P2-0 over pier P2 (medium) and on segment P2-2 (bottom).

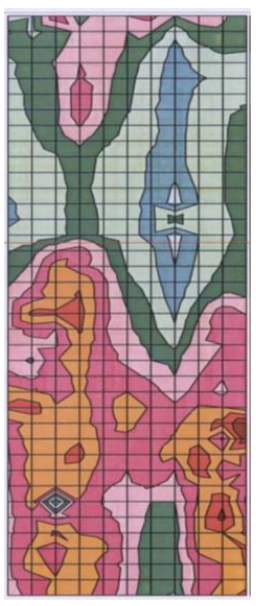

P2-0

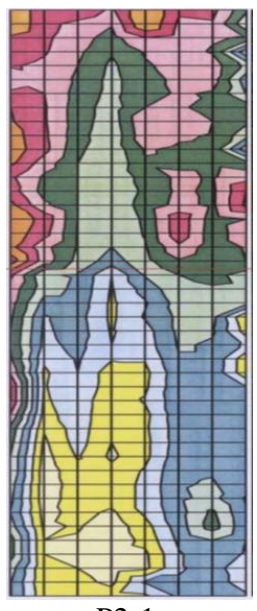

P2-1

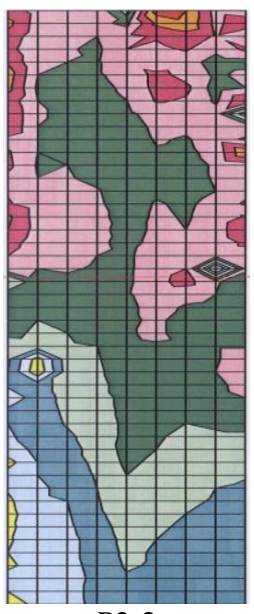

P2-2

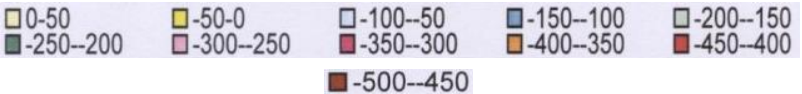

Fig. 6. Half-cell potential mappings for the three segments $\left(\mathrm{mV}, \mathrm{Cu} / \mathrm{CuSO}_{4}\right)$ 
Within the Cathodic Protection (CP) solutions, the impressed current (IC) technique was chosen rather than using sacrificial anodes (SA) because of the high content of chlorides present in the concrete - even deeper than the reinforcement. ICCP systems arrest steel reinforcement corrosion activity by supplying electrical current from an external source to overcome the ongoing corrosion current in the structure. A number of different anode system configurations are possible but in this case embedded anodes were chosen. They were drilled into the concrete from the interior of the girder offering three main advantages: (i) no traffic interruption, (ii) works could be done by daytime and (iii) no added load to the structure (as would have been the case with a titanium mesh and cementitious overlay).

It is to be noted that ICCP with embedded anodes in France is not a well-known technique and this trial aimed at improving our skills pointing out advantages and limits. The objectives for this research were to:

- Select and design the ICCP system

- Evaluate the performance of the ICCP with embedded anodes for reinforcement and presstressed tendons

- Monitor and control the system

- Establish recommendations for full-scale application

\subsection{ICCP with embedded anodes - Design, monitoring and installation}

The ICCP system with embedded anodes of the investigated field trial area on the three segments around P2 was designed considering several parameters:

- The surface area of the reinforcement to be protected was calculated for each segment,

- The prestressed tendons that could be in electrical continuity with the reinforcement were also calculated,

- The anodes (CPI) durAnodes (200mm long) or durAfat (50mm long) were made of MMO activated titanium; and were drilled into the concrete (the concrete thickness was around $200 \mathrm{~mm}$ ), and filled with the special compatible CP grout as developed by the anode supplier; locations (heights and depths) depended on the zones to be protected (one or two layers of reinforcement and space) as illustrated with a red cross in Fig. 7.

- The power source (and rectifier) and the targeted current density,

- The reference electrodes were essentially ERE20 $\left(\mathrm{Mn} / \mathrm{MnO}_{2}\right.$ ) (Force Technology) or decreased probes (coupons) durAmmo (CPI). Eight reference electrodes per segment were chosen to enable appropriate monitoring and control of the system. They were embedded at different heights and depths in concrete in order to monitor the behaviour of the reinforcement (one or two layers) and of the post-tensioning tendons. Locations of the reference electrodes are identified with a blue cross in Fig. 7 .

- The electronic devices (CPI), comprised a central system unit and three durAcenter slave devices (one for each segment).

Fig. 7 illustrates the zoning arrangement for each segment. It is to be noted that all the prestressed tendons of the three segments were gathered in zone 4 and were monitored with durAcenter 1 .

A permanently installed monitoring system allowed us to assess the performance of the cathodic protection based on eight reference electrodes $\left(\mathrm{Mn} / \mathrm{MnO}_{2}\right.$ type ERE20) per segment (Fig. 7). Remote monitoring was performed using a computer equipped with a modem.

Some pictures of the installation of the ICCP with embedded anodes in the Viaduc de Saint-Cloud are given in Fig. 8. During installation, polarity checks and continuity checks were tested.

\subsection{Results}

This section describes the findings obtained from the monthly monitoring of the segments over a period of 12 months and discusses in detail the findings.

No half-cell potential mapping was performed after the ICCP system installation as the external segment was repaired with a concrete overlay with a high resistance (to repair spalling and delamination or for aesthetic reasons)

With the monitoring system, output voltages and currents (Fig. 9) and instantaneous OFF steel/concrete potential (Fig. 10) were measured. The performance of the cathodic protection was evaluated based on the second criteria of the NF EN ISO standard 12696 [10]: "a potential decay over a maximum of $24 \mathrm{~h}$ of at least $100 \mathrm{mV}$ from Instantaneous OFF". Tab.1 presents the monthly calculated values of the potential decay.

From all these results (Fig. 9, 10 and Table. 1), it can be observed that during the first two months, the performance criteria was not achieved for all the reference electrodes (Tab 1, reference electrodes 1, 3, 4, 5 and 6 for segment P2-0; references 5, 6 and 8 for segment P2-1) and therefore adjustments of the voltage (and thus current) were made as can be observed on Fig.9; Fig. 9 also shows that the currents were higher in spring and summer and lower in autumn and winter. 


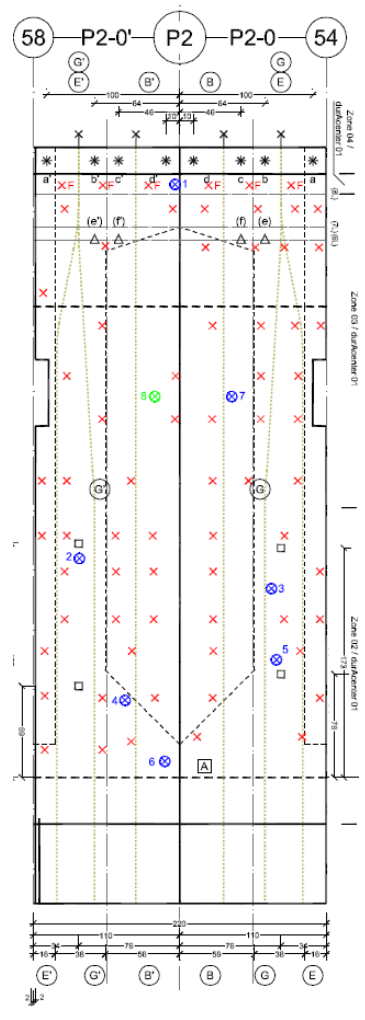

durAcenter 01

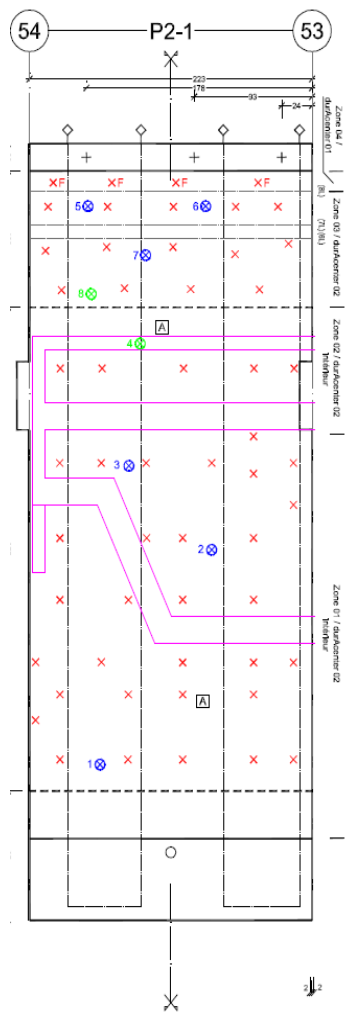

durAcenter 02
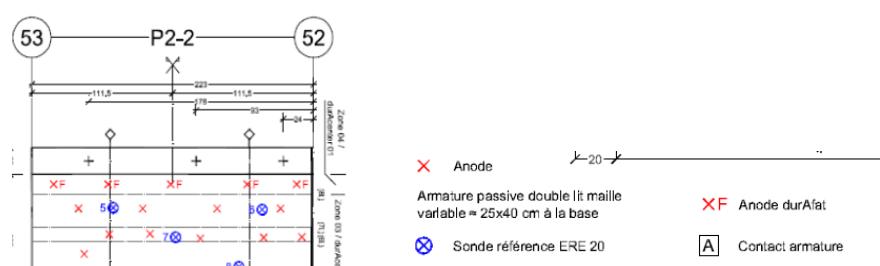

$\otimes$ Sonde rétérence ERE 20 A Contact armature

Q Sonde réérérence durAmmo $\square$ Chemin de cábles

Y Téte d'ancrage étrier aoll

+ Téte d'ancrage précontrainte transversale hourdis supérieur

$\ngtr \quad$ Tête d'ancrage précontrallite d'entretollse vous solrs ple P2(E/GB)

* Téte d'ancrage précontrainie d'entretotise voussolrs ple P2 (a-b-b-c-d)

$\Delta$ Tête d'ancrage prócontrainite d'entretotise hourdis superieur voussoirs pile P2 (e-f)

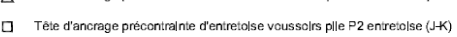

- Trou de montage

.. Tracé gaines precontraintes

EA- Etrleractff

$\frac{\varphi}{x}$

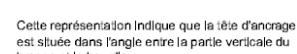

Fig. 7. Zoning arrangements for the three segments P2-0 (zones 2, 3 and 4), P2-1 (zones 1, 2 and 3) and P2-2 (zones 1, 2 and 3). Size of one segment is $2.2 \mathrm{~m}$ wide ( $2 \mathrm{~m}$ for segment over pier), $5.5 \mathrm{~m}$ high and $0.2 \mathrm{~m}$ thick.

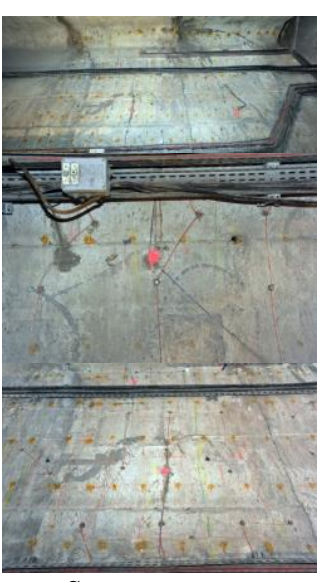

Segment zones

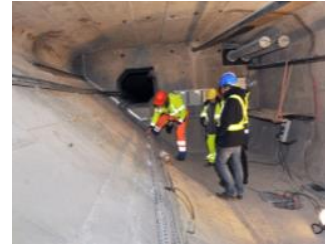

Interior of $\mathrm{P} 2$ segment

\section{Reference electrode} (ERE20)

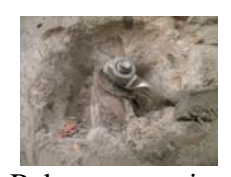

Rebar connection

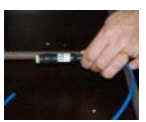

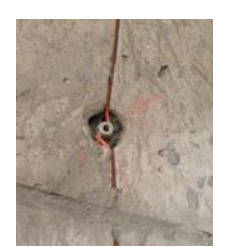

Embedded anode connection

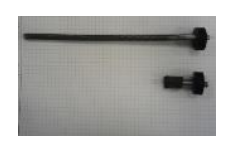

Anodes (durAnode (top) durAfat (bottom))

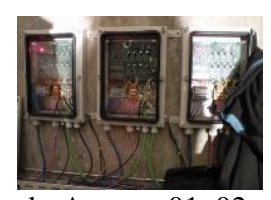

durAcenter 01, 02 and 03

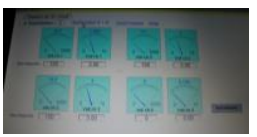

Voltage and current monitoring

Fig. 8. Illustration of the installation of the ICCP system with embedded anodes in the Viaduc de Saint-Cloud. 

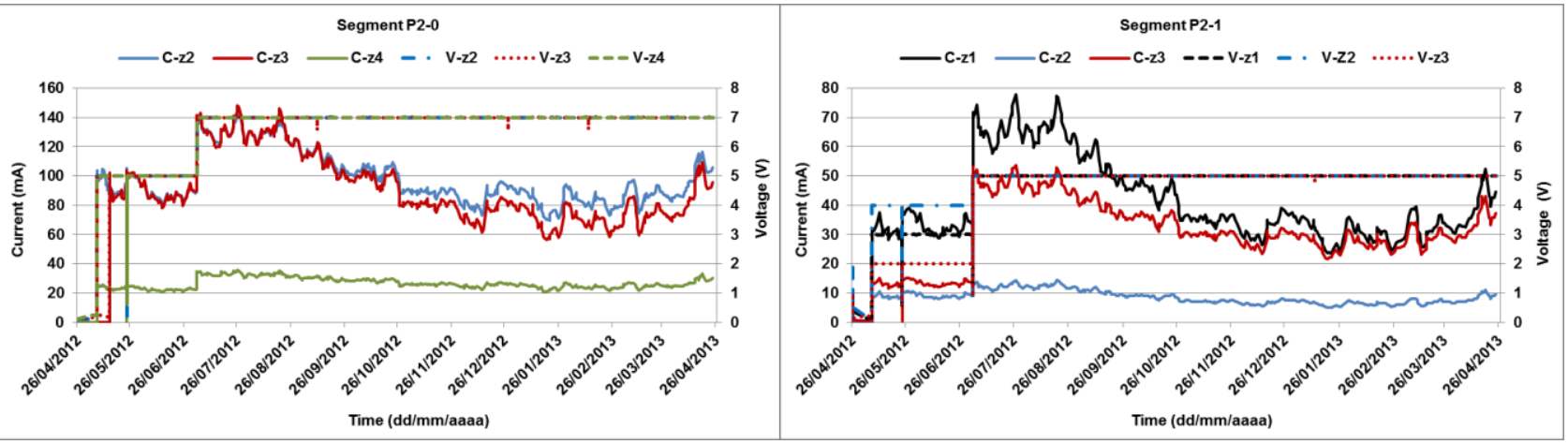

Fig. 9. Current and voltage measurements during the twelve months trial, segment P2-0 (left) and segment P2-1 (right).
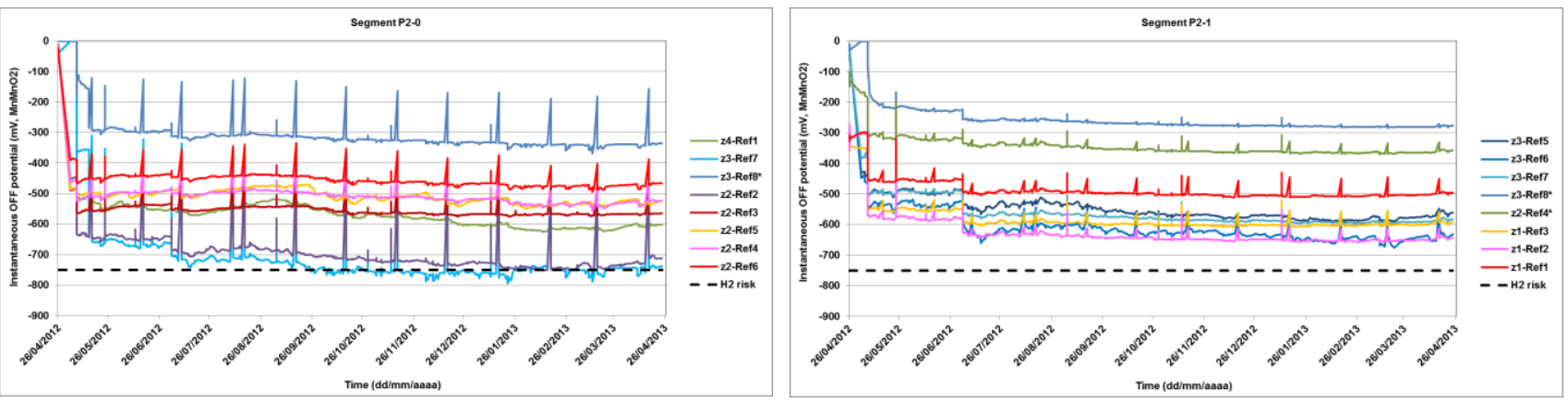

Fig. 10. Instantaneous OFF potential of the eight reference electrodes during the twelve month trial; segment P2-0 (left) and segment P2-1 (right) (the peaks correspond to the monthly verification of depolarisation ISO 12696).

Fig 10 illustrates instantaneous OFF potential of the eight references per segment depending on their locations (segment P2-0: 5, 2 and 1 references respectively in zones 2, 3 and 4; segment P2-1: 3, 1 and 3 references respectively in zones 1,2 and 3 ).

Zone 4 of Fig 10 left includes the prestressed tendons of the three segments. These latter results also allowed us to verify that there was no risk of hydrogen embrittlement: the green curve relative to the reference located close to the prestressed tendons (zone 4) was not close to the hydrogen risk represented by the dotted line.

After the two months energizing period, the performance was $100 \%$ achieved for the three zones of segment P2-2 and segment P2-1 (except for reference electrode 8 but which was not a manganese reference) (Tab. 1). The conclusion was different for the segment over pier P2 (durAcenter 01 in Tab.1). In zone 4 (Ref 1) and zone 2 (Ref 5 only) the performance criteria failed. This result was explained by the presence of the whole prestressed tendons from the three segments in zone 4 and by the presence of concentrated longitudinal and transversal prestressed tendons in zone 2 . In order to improve the cathodic protection where larger density of steel was present due to presstressed tendons, a larger anodic surface area was proposed (embedded anodes + ribbon or mesh).

Table 2 summarizes the averaged results obtained after the energizing period for the three segments. The design calculation was made based on an assumption of $15 \mathrm{~mA} / \mathrm{m}^{2}$ of steel surface. The operating currents were in the range 2.1 to $8.8 \mathrm{~mA} / \mathrm{m}^{2}$ of steel surface. The current per anode per zone was in the range 1.2 to $3.2 \mathrm{~mA}$ and was in good agreement with the purchased anodes (maximum current of $4.4 \mathrm{~mA}$ or $3.0 \mathrm{~mA}$ respectively for durAnode and durAfat (CPI Denmark)). A life expectancy of more than 25 years was expected.

Table 1. Monthly potential decay values during the twelve months trial for segments P2-0, P2-1 and P2-2 (green colour indicates a pass value whereas orange or red colours a failed value).

\begin{tabular}{|c|c|c|c|c|c|c|c|c|c|c|c|c|}
\hline \multirow{2}{*}{\begin{tabular}{|l|} 
Year \\
Month \\
\end{tabular}} & \multicolumn{8}{|l|}{2012} & \multicolumn{4}{|l|}{2013} \\
\hline & 5 & 6 & 7 & 8 & 9 & 10 & 11 & 12 & 1 & 2 & 3 & 4 \\
\hline durAcents & \multicolumn{12}{|c|}{ Segment P2-0 (zone 4 including the prestressed tendons of the three segments) } \\
\hline z4-Ref1 & 33 & 27 & 34 & 39 & 37 & 35 & 33 & 29 & 28 & 28 & 27 & 28 \\
\hline z3-Ref7 & 344 & 352 & 399 & 381 & 380 & 384 & 362 & 352 & 356 & 312 & 308 & 323 \\
\hline z3-Ref8* & 170 & 174 & 192 & 189 & 187 & 174 & 172 & 171 & 174 & 177 & 167 & 186 \\
\hline z2-Ret2 & 204 & 224 & 259 & 277 & 277 & 280 & 304 & 265 & 287 & 269 & 302 & 285 \\
\hline z2-Ref3 & 81 & 86 & 102 & 106 & 118 & 105 & 106 & 102 & 107 & 102 & 100 & 87 \\
\hline z2-Ref5 & 25 & 24 & -6 & 31 & 37 & 27 & 26 & 12 & 16 & 16 & 16 & 21 \\
\hline z2-Ref4 & 72 & 78 & 88 & 102 & 112 & 109 & 112 & 83 & 96 & 65 & 75 & 85 \\
\hline z2-Ref6 & 82 & 85 & 91 & 103 & 111 & 107 & 106 & 95 & 97 & 89 & 83 & 86 \\
\hline \multicolumn{13}{|c|}{ durAcenter 02 Segment P2-1 } \\
\hline z3-Ret5 & 53 & 44 & 114 & 141 & 146 & 138 & 147 & 133 & 139 & 135 & 135 & 133 \\
\hline z3-Ref6 & 95 & 66 & 194 & 221 & 209 & 200 & 202 & 181 & 189 & 191 & 203 & 213 \\
\hline z3-Ref7 & 120 & 113 & 194 & 218 & 213 & 190 & 195 & 175 & 181 & 173 & 172 & 186 \\
\hline z3-Ref8* & 60 & 58 & 89 & 110 & 102 & 81 & 81 & 69 & 70 & 64 & 64 & 76 \\
\hline z2-Ref4* & 139 & 137 & 154 & 176 & 175 & 152 & 152 & 134 & 138 & 127 & 128 & 138 \\
\hline z1-Reł3 & 199 & 206 & 251 & 259 & 258 & 244 & 239 & 228 & 225 & 213 & 215 & 227 \\
\hline z1-Ref2 & 265 & 269 & 318 & 323 & 321 & 308 & 301 & 296 & 289 & 290 & 288 & 306 \\
\hline z1-Ref1 & 162 & 167 & 211 & 214 & 218 & 211 & 208 & 198 & 202 & 193 & 195 & 199 \\
\hline \multicolumn{13}{|c|}{ durAcenter 03 Segment P2-2 } \\
\hline z3-Ref8 & 187 & 214 & 270 & 289 & 302 & 286 & 290 & 282 & 283 & 278 & 282 & 280 \\
\hline z3-Ref7 & 121 & 127 & 151 & 164 & 168 & 163 & 165 & 164 & 165 & 163 & 164 & 158 \\
\hline z3-Ref6 & 82 & 97 & 121 & 144 & 152 & 144 & 153 & 144 & 152 & 147 & 148 & 139 \\
\hline z3-Ret5 & 78 & 78 & 102 & 116 & 119 & 118 & 124 & 123 & 131 & 133 & 127 & 124 \\
\hline z2-Ref4 & 288 & 292 & 318 & 330 & 334 & 313 & 315 & 296 & 302 & 293 & 295 & 292 \\
\hline z1-Ref3 & 310 & 314 & 375 & 375 & 376 & 360 & 353 & 343 & 342 & 335 & 334 & 334 \\
\hline z1-Ref2 & 337 & 346 & 419 & 414 & 416 & 406 & 400 & 395 & 388 & 383 & 382 & 389 \\
\hline z1-Ref1 & 122 & 126 & 157 & 159 & 162 & 153 & 149 & 144 & 145 & 146 & 142 & 145 \\
\hline
\end{tabular}


Table 2. Average results for the 10 months period after energizing.

\begin{tabular}{|c|c|c|c|c|c|c|c|c|c|c|c|c|c|c|c|}
\hline & Segment & \multicolumn{6}{|c|}{ Protected zone as designed } & \multicolumn{3}{|c|}{ Reference electrodes } & \multicolumn{4}{|c|}{$\begin{array}{l}\text { Average values for results } \\
\text { obtained from July } 2012 \text { to April } 2013\end{array}$} & \multirow{2}{*}{\begin{tabular}{|c}
$\begin{array}{c}\text { Performance } \\
\text { criteria }\end{array}$ \\
$\begin{array}{c}\% \text { month } \\
\text { (pass) }\end{array}$
\end{tabular}} \\
\hline & Name & $\begin{array}{c}\text { Zone } \\
\text { number }\end{array}$ & $\begin{array}{l}\text { Location } \\
\text { (height of } \\
\text { segment) }\end{array}$ & $\begin{array}{c}\text { Concrete } \\
\text { surface } \\
\left(\mathrm{m}^{2}\right)\end{array}$ & $\begin{array}{l}\text { Steel density } \\
\left(\mathrm{m}^{2} \text { steel }\right. \\
\left./ \mathrm{m}^{2} \text { concrete }\right)\end{array}$ & $\begin{array}{l}\text { Anode } \\
\text { type }\end{array}$ & $\begin{array}{l}\text { Number of } \\
\text { anode/zone }\end{array}$ & $\begin{array}{c}\text { Ref } \\
n^{\circ}\end{array}$ & \begin{tabular}{|c|} 
Number of \\
reference \\
electrode \\
per zone
\end{tabular} & $\begin{array}{c}\text { Depth } \\
(\mathrm{cm})\end{array}$ & $\begin{array}{l}\text { Voltage } \\
\text { (V) }\end{array}$ & $\begin{array}{c}\text { Total } \\
\text { current/zone } \\
(\mathrm{mA})\end{array}$ & $\begin{array}{l}\text { Current density } \\
\text { per zone } \\
\left(\mathrm{mA} / \mathrm{m}^{2} \text { steel }\right)\end{array}$ & $\begin{array}{l}\text { Current per } \\
\text { anode/zone } \\
(\mathrm{mA})\end{array}$ & \\
\hline \multirow{4}{*}{ 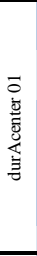 } & P2-0/P2-1/P2-2 & 4 & $\begin{array}{c}\text { prestressed } \\
\text { tendons }\end{array}$ & 1.82 & 1.75 & durAfat & 15 & 1 & 1 & 10 & 7 & 28 & 8.8 & 1.9 & 0 \\
\hline & P2-0 & 3 & medium & 5.14 & 3.29 & durAnode & 32 & $\begin{array}{c}7 \\
8^{*}\end{array}$ & 2 & $\begin{array}{l}20 \\
13\end{array}$ & 7 & 93 & 5.5 & 2.9 & $\begin{array}{l}100 \\
100\end{array}$ \\
\hline & P2-0 & 2 & bottom & 5.14 & 2.41 & durAnode & 31 & $\begin{array}{l}2 \\
3 \\
5 \\
4 \\
6\end{array}$ & 5 & $\begin{array}{l}10 \\
10 \\
10 \\
10 \\
10\end{array}$ & 7 & 100 & 8.1 & 3.2 & $\begin{array}{c}100 \\
90 \\
0 \\
40-50 \\
40-60\end{array}$ \\
\hline & - & 1 & - & - & - & - & - & - & - & - & - & - & - & - & - \\
\hline \multirow{4}{*}{ 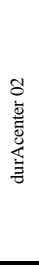 } & *durAcenter 01 & 4 & $\begin{array}{c}\text { prestressed } \\
\text { tendons }\end{array}$ & 1.82 & - & durAfat & (4) & - & - & - & - & - & - & - & - \\
\hline & P2-1 & 3 & top & 1.70 & 2.27 & durAnode & 14 & $\begin{array}{c}5 \\
6 \\
7 \\
8^{*}\end{array}$ & 4 & $\begin{array}{l}10 \\
10 \\
10 \\
8\end{array}$ & 5 & 35 & 9.1 & 2.5 & $\begin{array}{l}100 \\
100 \\
100 \\
20\end{array}$ \\
\hline & P2-1 & 2 & medium & 1.98 & 1.51 & durAnode & 5 & $4^{*}$ & 1 & 20 & 5 & 9 & 3.0 & 1.8 & 100 \\
\hline & P2-1 & 1 & bottom & 6.60 & 1.00 & durAnode & 31 & $\begin{array}{l}3 \\
2 \\
1 \\
\end{array}$ & 3 & $\begin{array}{l}10 \\
20 \\
10 \\
\end{array}$ & 5 & 44 & 6.7 & 1.4 & $\begin{array}{l}100 \\
100 \\
100 \\
\end{array}$ \\
\hline \multirow{4}{*}{ 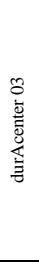 } & *durAcenter 01 & 04 & $\begin{array}{c}\text { prestressed } \\
\text { tendons }\end{array}$ & - & - & durAfat & (5) & - & - & - & - & - & - & - & - \\
\hline & P2-2 & 03 & top & 1.70 & 2.23 & durAnode & 14 & $\begin{array}{l}8 \\
7 \\
6 \\
5\end{array}$ & 4 & $\begin{array}{l}10 \\
10 \\
10 \\
10\end{array}$ & 6 & 30 & 7.9 & 2.1 & $\begin{array}{l}100 \\
100 \\
100 \\
100\end{array}$ \\
\hline & $\mathrm{P} 2-2$ & 02 & medium & 1.98 & 1.47 & durAnode & 5 & 4 & 1 & 20 & 5 & 6 & 2.1 & 1.2 & 100 \\
\hline & P2-2 & 01 & bottom & 6.60 & 0.97 & durAnode & 29 & $\begin{array}{l}3 \\
2 \\
1\end{array}$ & 3 & $\begin{array}{l}20 \\
10 \\
20\end{array}$ & 5 & 39 & 6.1 & 1.3 & $\begin{array}{l}100 \\
100 \\
100\end{array}$ \\
\hline
\end{tabular}

* DurAmmo

\section{CONCLUSIONS}

Cathodic protection systems are capable of providing a significantly larger extension in service life compared with other corrosion mitigation systems.

In France, to address the chloride induced corrosion of the Viaduc de Saint-Cloud where access and traffic management are challenging, Impressed Current Cathodic Protection with embedded anodes has been tested. In this ICCP system a small current is passed from a permanent anode to the reinforcing steel. It involves the permanent installation of a low voltage, controlled electrical system which passes a direct current to the steel so that the steel is made into a cathode, thus preventing the steel from corroding. The ICCP system was mainly installed from the interior of the bridge, thus allowing significant cost savings without interrupting the traffic which was another advantage. This electrochemical treatment provided protection to the steel that was monitored monthly and controlled over a period of twelve months.

Based on the results of this field trial, the following conclusions were drawn:

- The designed ICCP system was achieving a satisfactory protection for segments $\mathrm{P} 2-1$ and $\mathrm{P} 2-2$.

- For the segment over pier P2, the ICCP was partly unsuccessful as designed and needed some improvements mainly in the area involving the prestressed tendons,

- For prestressed tendons, the risk of hydrogen embrittlement was not observed. In the areas whith large reinforcement density (rebars and prestressed) the field trial has demonstrated the need to increase the value of the protective current. This could be achieved with the application of a "surface" anode (titanium mesh).

This research provided some technical information to establish recommendations for full-scale application of ICCP with embedded anodes in the Viaduc de SaintCloud which counts 518 segments, 16 segments over piers and 16 special segments. It also helped us to acquire technical skills to implement this electrochemical technique and provided financial information for the total cost of repair of the bridge. Finally, it is important to point out that the cost of the field trial only represented $2 \%$ of the full-scale repair cost and was therefore worth doing.

It should also be emphasized that people involved in this kind of electrochemical rehabilitation treatment need to acquire sufficient skills to understand how the system works. CP repair therefore needs trained personnel in house or formally certified persons [11].

For future research, the full scale bridge repair should be studied in order to estimate the long term durability of such a treatment and its maintenance.

\section{ACKNOWLEDGEMENTS}

The authors are grateful to the following persons involved in the field trial: P. Peyrac, A. Jacquel, K. Gremillon, T. Sauvageon et J. Desille from DiRIF, T. Kretz, B. Godart et L. Gaillet from Ifsttar, F. Landrin, M. Landrin et JL Saussol from Cerema, M. Grill from In-Situ SA, L. Serra, P. Ballerand et L. Fontaine from Spie Batignolles, S. Lorang et S. Butaud from Iraco, and J. Crouzillac from BAC. The authors are also grateful to the persons of the technical committee of Viaduc de Saint-Cloud for technical and financial discussion and particularly to E. Humbert who lead this committee. 
This field trial was funded by the DiRiF (Direction interdépartementale des Routes d'île de France).

\section{References}

1. https://structurae.info/ouvrages/viaduc-de-saintcloud (in French)

2. AFPC-AFREM, Durabilité des bétons : Mode opératoire recommandé pour l'extraction et le dosage des chlorures libres et totaux dans le béton, LMDC Toulouse, (1997)

3. B. Elsener, RILEM TC 154-EMC:Electrochemical Techniques for Measuring Metallic Corrosion Recommendations - Half-cell potential measurements - Potential mapping on reinforced concrete structures. Materials and Structures, 36: $\mathrm{p}$. 461-471, (2003)

4. GP. Tilly, J. Jacobs, CONREPNET - Concrete repairs - Performance in service and current practice. United Kingdom, IHS BRE Press, ISBN 978-1-86081-974-2, (2007)

5. L. Etcheverry, D. W. Fowler, H. G. Wheat and D. P. Whitney, Evaluation of cathodic protection systems for marine bridge substructures, Texas Department of Transportation, Research report 7-2945, (1998)

6. L. Bertolini, F. Bolzoni, A. Cigada, T. Pastore, P. Pedeferri. Cathodic protection of new and old reinforced concrete structures, Corrosion Science, 35(5-8):1633-1639, (1993)

7. L. Lazzari, P. Pedeferri, Cathodic protection, Polipress ed. Milano, ISBN 88-7398-020-1, (2006)

8. AA. Sohanghpurwala, Cathodic protection for life extension of existing reinforced concrete bridge elements, National Cooperative Highway Research Program Synthesis 398, editor. Washington DC, Transportation Registration Board, ISBN 978-0309-09839-7, (2009)

9. Wilson K, Jawed M, Ngala V. The selection and use of cathodic protection systems for the repair of reinforced concrete structures. Construction and Building Materials, 39:19-25, (2013).

10. NF EN ISO 12696 standard, Cathodic protection of steel in concrete, AFNOR, (2017)

11. NF EN ISO 15257 standard, Cathodic protection Competence levels of cathodic protection persons Basis for certification scheme, (2017) 